\section{ICT-Driven Writing and Motor Skills: A Review}

\author{
John Fredy Patiñoa, Andrés Leonardo Calixtob ${ }^{\mathrm{b}}$, Andrés Chiappe ${ }^{*, c}$, \\ Fanny Teresa Almenarez ${ }^{d}$
}

\begin{tabular}{ll}
\hline Received: & 14 January 2020 \\
Revised: $\quad 29$ May 2020 \\
Accepted: $\quad 20$ June 2020 \\
ISSN: $1307-9298$ \\
Copyright C IEJEE \\
www.iejee.com
\end{tabular}

DOI: 10.26822/iejee.2020562139

\title{
Abstract
}

The development of writing skills is recognized as a mandatory process for initial education and the foundation of all essential learning. Writing skills are crucial to children's socialization and interaction with their environment as they grow. The development of writing skills has been linked to a complex set of key factors, but is not yet clear enough. In the context of 21 st-century education, and to increase understanding of this phenomenon, a systematic literature review of 40 years of published studies on the subject was carried out. The results revealed how relevant the integration of gross and fine motor skills is, along with the use of Information and Communication Technologies (ICT). The development of writing skills in game-based learning environments and curricular articulation of physical education and ICT-mediated writing in early childhood education are also significant factors to consider.

Keywords: Writing Skills, Gross Motor Skills, Educational Technology, Collaborative Writing

\section{Introduction}

A priority in educational systems around the world is the development of writing skills in children. Writing is not only the way to express their emotions and feelings, but the mainstay of their communication and socialization development (Akkaya \& Kırmızı, 2010).

There are multiple perspectives on the acquisition of writing skills: language proficiency (Maftoon \& Seyyedrezaei, 2012; Tengku-Mahadi et al., 2018), global familiarization with the graphic code (Kiiveri \& Määttä, 2012; Romero et al., 2005), psychomotor condition (Barbot et al., 2012; Erdogan, 2011), and the laterality and direction of the stroke (León et al., 2017; Sitnikova, 2012). However, the key factor to consider is progressiveness: to lay the substrate of writing skills development it is necessary to generate enough gross motor patterns and eye-hand coordination in children in order to be able to gradually generate subsequently finer motor processes (Gaul \& Issartel, 2016).

In this regard, Smitha and Renumol (2018) defined the proper development of fine motor skills as what allows the schoolage child to correctly perform basic positions and movements for writing. This includes the ability to make a fist, the proper finger-to-thumb opposition, and repetitive tapping. In addition, De Juanas Oliva (2014) highlighted brain lateralization as relevant, along with its consequential strengthening of a preferred skillful hand to use in writing.

In such a context, teachers responsible for physical education must work together with writing teachers. In fact, physical education activities should provide the child awareness about breathing, muscular tension, fatigue, and relaxation (Ghahari \& Farokhnia, 2017); such proprioception should allow them to overcome adverse conditions for the development of writing. In this regard, Weigel, Martin and Bennett (2010) showed family routines and resources as well as tension and stress in students as hindrance factors to proper writing as required by the school system.
In the absence of ICT, the child must properly develop certain basic pre-writing motor skills before learning to write. The main one is pictography, the exercise of drawing as an articulated expression of thoughts and motor development (Mackenzie \& Veresov, 2013). However, in the context of a hyperconnected and increasingly digitally-mediated world, writing skills and their prior motor development are different from the ones that children acquire in traditional teaching contexts. The widespread use of digital and mobile devices such as tablets or smartphones entails a different understanding of writing skills.

Hence, alternative writing instruction methods based on the use of Information and Communication Technologies (ICT) have emerged. The pervasive use of keyboards and touch screens made writing skills a matter of distinguishing graphs or letters without learning the handwriting stroke, thus avoiding previous stages such as scribbling (Mangen \& Balsvik, 2016; Vertecchi et al., 2016).

In this sense, Genlott and Grönlund (2013) designed the "Integrated Write to Learn" method (iWTR), an experimental way to teach children the minimum skills required for handling digital devices (turning them on and off, entering and closing a text editor, using the keyboard, etc.), and later teaching them to write with them. Through the use of digital media it was possible to help the children build words, acquire a lexicon and then collaboratively create coherent sentences and texts.

An initial search on the topic showed the comparative volume of research on ICT-related writing skills vs non-ICT writing skills (Figure 1 ).

The use of ICTs in learning has shown positive effects on children's motor development (Strand \& Nielsen, 2017), and a very high potential to transform teaching in primary education (Martínez Parejo, 2016). However, it is necessary to develop a better understanding of the effects and relationships between motor development, writing skills and the use 


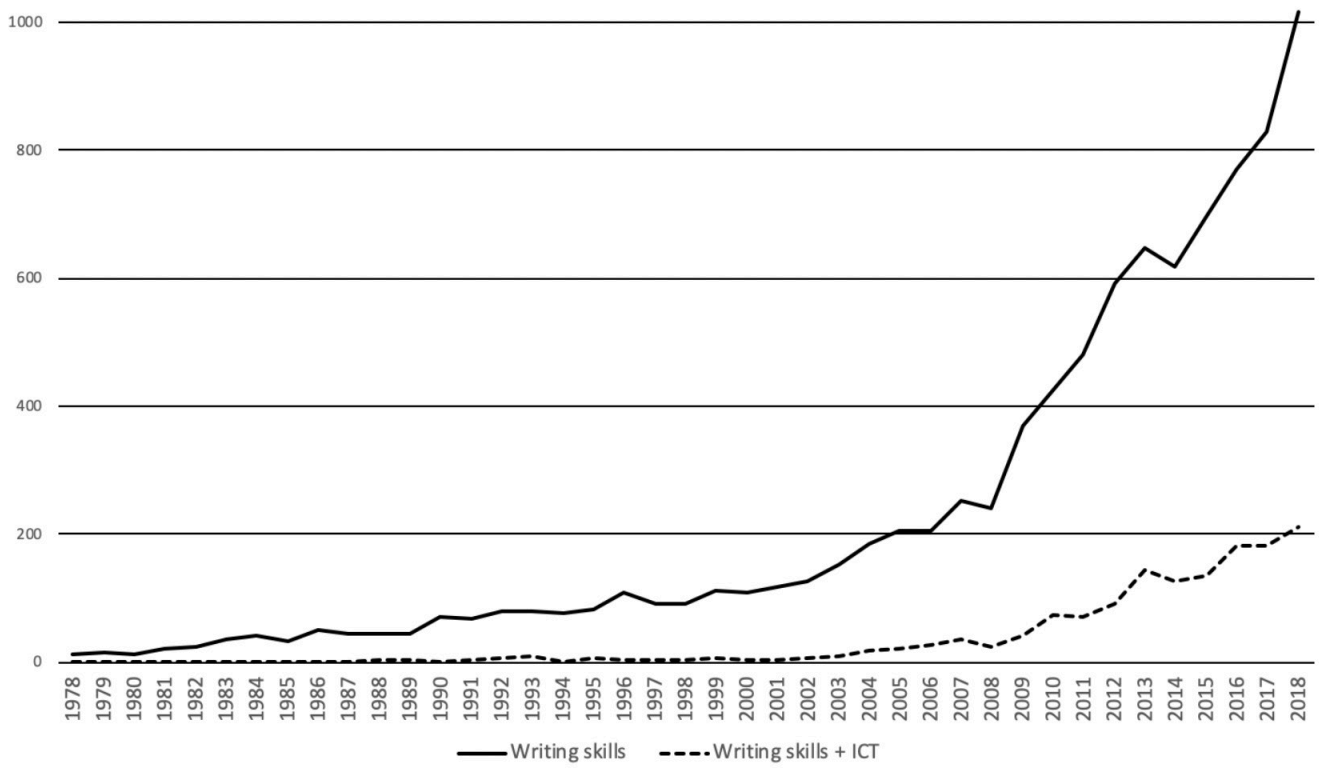

Figure 1. Comparative of Writing Skills Research with/without an ICT Component Source: Own elaboration based on Scopus data

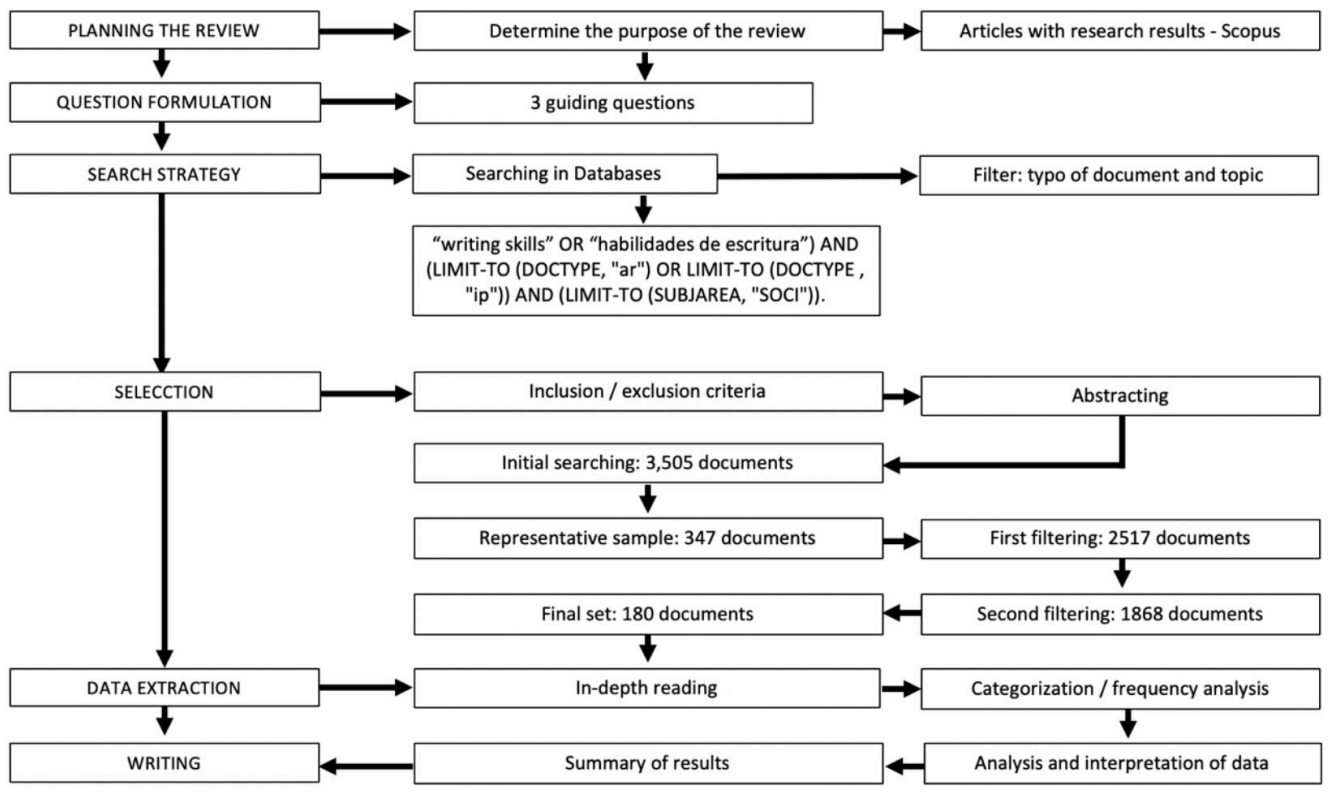

Figure 2. Review Method

Source: Own elaboration

of ICT. This systematic review of scholarly literature on writing skills aimed to identify commonalities between the use of ICT and the development of gross motor skills. By articulating curricular and didactic trends in both areas, a paradigm shift may emerge in primary education.

\section{Method}

This review followed the steps by Lavallee, Robillard \& Mirsalari (2014), as shown in Figure 2:

\section{Planning the Review}

In this first step, the team established the purpose of the review, the type of documents to be reviewed, and the sources to retrieve them. The review focused on key factors for the development of writing skills, particularly to identify which of them are acquired through the development of gross motor skills and which are susceptible to be obtained directly with ICT. The search was limited to research articles published in
Scopus-listed journals, since the Scopus database has the highest coverage of high-impact indexed publications in the social sciences. Additionally, the strict application of peer review processes and rigorous acceptance and rejection criteria make Scopus journals high quality sources for a scholarly literature review.

\section{Guiding Questions for the Review}

Three main guiding questions were defined as review drivers: (1) What are the key factors in the development of writing skills? (2) Which of those key factors are directly linked to the development of gross motor patterns? and, (3) Which of those key factors may be augmented through the use of ICT?

\section{Search Strategy Definition}

First, the Scopus database was queried by type of document and subject, restricting results to articles in the social sciences. The following search criteria and boolean operators were 
chained and then queried over Scopus: ("writing skills" OR "writing competencies") AND (LIMIT-TO (DOCTYPE, "ar") OR LIMIT-TO (DOCTYPE, "ip")) AND (LIMIT-TO (SUBJAREA, "SOCI")).

\section{Article Selection}

The initial criterion for article inclusion was the presence of the search terms either in the title or in the abstract. The second criterion was that each article included results of a study on the subject area. Based on the results of an initial search, only articles published in the last 40 years were finally included.

The initial search yielded 3,505 documents, for which a representative sample was calculated $(n=347)$ with a $95 \%$ reliability and $5 \%$ error. Then, a first filtering limited the search to "articles and articles in press" ( $n=2517)$, and a second filtering by subject area limited results to "Social Sciences" $(n=1868)$. The articles were sorted by number of citations in descending order to ensure the highest level of acceptance by the academic community. Filtering by subject area guarantees to stay within the framework of educational research, which in turn is labeled under "Social Sciences".

After the filtering processes reduced the corpus $(N=1868)$, a proportional sample was determined $(n=180)$. The reduced sample kept the proportionality of articles per year, as follows:

$$
\begin{aligned}
& \text { - From } 1978 \text { to 1998: } 18.33 \%(n=33) \text {. } \\
& \text { - From } 1999 \text { to 2006: 31.66\% }(n=57) \text {. } \\
& \text { - From } 2007 \text { to } 2018: 50 \%(n=90) \text {. }
\end{aligned}
$$

\section{Data extraction and synthesis}

In an in-depth reading process, key ideas were extracted from each reviewed article, and added to the analysis matrix after having been approved. The data in this matrix was sorted by publication time, organized in time periods, and then terminologically unified and categorized. Additionally, a co-occurrence analysis was conducted to identify terms with the highest frequency of appearance and connections between those key ideas.

As a triangulation process, an adequate level of inter-rater assessment for the dataset in the analysis matrix (Warrens, 2013) was established. Key ideas were extracted by two different observers, whose results were checked by determining their mutual Cohen's Kappa coefficient $(k=.538)$. An $82 \%$ of agreement was established from there. After nine (9) items were identified to be in disagreement between observers, they were excluded from the overall analysis.

\section{Results}

\section{Bibliometric results}

The reviewed articles $(N=180)$ were published in 87 journals in a relatively homogeneous manner. Most journals contributed only one article to the reviewed corpus (60.9\%; $n=53)$, while $20.7 \%$ of them $(n=18)$ contributed two articles, and another $6.9 \%(n=6)$ contributed three articles. The remaining ten journals were the most relevant: $4.5 \%(n=4)$ contributed 4 articles, $1.15 \%(n=1)$ contributed 5 articles, 3.45\% $(n=3)$ contributed 6 articles, another $1.15 \%(n=1)$ contributed 7 articles and finally, another $1.15 \%(n=1)$ contributed 15 articles.

Table 1 showed the top ten journals by article contribution, with their impact factors and location on the SCImago journal rank (SJR) quartile scale, an indication of the quality of the consulted sources.

Additionally, Table 2 shows the 2017-2018 set of articles with their key ideas and impact factor.

A qualitative categorization process with co-occurrence analysis was conducted (Figure 3 ), which showed that writing skills were directly related to gross motor skills.

\section{Key ideas related to the development of writing skills}

The data analysis yielded a set of 55 key ideas related to the development of writing skills. Figure 4 shows the top 10 key ideas by frequency of appearance in the reviewed articles.

It is also worth mentioning both the topical wide scope of those key ideas and their scattering among the articles reviewed: five (5) key ideas (9.1\%) appeared between 20 and 86 times; eight (8) key ideas (14.5\%) appeared between 10 and 19 times; thirteen (13) key ideas (23.6\%) appeared between 5 and 9 times; sixteen (6) key ideas (29.1\%) appeared between 2 and 4 times; and, thirteen (13) key ideas (23.6\%) appeared only once.

To begin with, Hier and Eckert (2016), Maldarelli, Khars, Hunt and Lockman (2015), Ahmed, Wagner and López (2014), Olinghouse and Graham (2009), considered that handwriting (6.7\%) represented a very important factor in the development of writing skills insofar as it contributes to fluency. Handwriting develops the quality and direction of the stroke, as well as the quality of the graphs and line tracings, which later lead to better reading. As the child's graphs evolve from scribbling to proper writing, the brain is better trained in shape recognition, hence improving its own reading and, progressively, the quality of the spelling.

Table 1. Top 10-Journals with more articles reviewed

\begin{tabular}{lrrrr}
\hline Journal & $\begin{array}{r}\text { Articles by } \\
\text { journal }\end{array}$ & $\begin{array}{r}\text { JCR } \\
\text { impFctr }\end{array}$ & $\begin{array}{r}\text { SJR } \\
\text { impFctr }\end{array}$ & $\begin{array}{r}\text { SJR } \\
\text { Quartile }\end{array}$ \\
\hline Reading and Writing & 15 & 1.837 & 1.462 & Q1 \\
\hline Journal of Educational Psychology & 7 & 4.433 & 3.459 & Q1 \\
\hline Early Childhood Education Journal & 6 & 0.927 & 0.597 & Q2 \\
\hline Journal of Second Language Writing & 6 & 3.324 & 2.657 & Q1 \\
\hline Journal of Writing Research & 6 & N/A & 1.035 & Q1 \\
\hline Computers \& Education & 5 & 4.538 & 2.323 & Q1 \\
\hline British Journal of Educational Psychology & 4 & 2.057 & 1.399 & Q1 \\
\hline Journal of School Psychology & 4 & 2.299 & 1.751 & Q1 \\
\hline Learning and Individual Differences & 4 & 1.420 & 1.129 & Q1 \\
\hline Written Communication & 4 & 1.267 & 0.730 & Q1 \\
\hline Source: Own elaboration based on Scopus and WoS data & & &
\end{tabular}


Table 2. Key ideas by article 2018-2017

\begin{tabular}{|c|c|c|}
\hline Source & Key ideas in article & $\begin{array}{r}\text { Field- } \\
\text { Weighted } \\
\text { Citation } \\
\text { Impact }\end{array}$ \\
\hline (Suggate et al., 2018) & $\begin{array}{l}\text { Cognitive and social skills, graphomotor or neuromotor skills, fine motor skills, early reading / emerging } \\
\text { reading }\end{array}$ & 6.22 \\
\hline (McMaster et al., 2018) & $\begin{array}{l}\text { Planning, review, writing strategy, early writing / emerging writing, transcription, text generation and } \\
\text { composition }\end{array}$ & 5.11 \\
\hline $\begin{array}{l}\text { (Belet Boyacı \& Güner, } \\
\text { 2018) }\end{array}$ & Skills list, joy of writing, authentic material & 1.02 \\
\hline (Spengler et al., 2018) & Skills list, cognitive and social skills & 4.28 \\
\hline (Sauvé et al., 2018) & Skill/ability, skills list, cognitive and social skills, planning, review, writing strategy & 3.05 \\
\hline (Pennington et al., 2018) & Interrelations and change, ICT mediation, disability, differences between written and spoken & 2.64 \\
\hline (Gutiérrez-Fresneda, 2018) & $\begin{array}{l}\text { Skill/ability, skills list, grammar or spelling, handling punctuation, early writing / emerging writing, pho- } \\
\text { nological awareness \& phonology, written code \& written language, oral language / oral narrative, speed } \\
\text { nomenclature }\end{array}$ & 0.77 \\
\hline (Aghajani \& Adloo, 2018) & ICT intermediation, joy of writing, internet as a writing tool, text generation and composition & 1.02 \\
\hline (Sulak, 2018) & ICT mediation, internet as a writing tool, writing in elementary teaching & Not yet \\
\hline (Puranik et al., 2018) & $\begin{array}{l}\text { Skill / ability, early reading / emerging reading, parents teaching writing, early writing / emerging writing, } \\
\text { oral language and oral narrative }\end{array}$ & 0.79 \\
\hline $\begin{array}{l}\text { (Weston-Sementelli et al., } \\
\text { 2018) }\end{array}$ & Text generation essays, reading and writing combination & 0.71 \\
\hline (Zhang \& Quinn, 2018) & Early writing / emerging writing, emerging literacy & 1.54 \\
\hline (Spencer \& Petersen, 2018) & $\begin{array}{l}\text { Early writing / emerging writing, transcription, written codes \& written language, oral language and oral } \\
\text { narrative }\end{array}$ & Not yet \\
\hline (Koutsoftas, 2018) & Skill / ability, skill, phonological awareness \& phonology & 2.03 \\
\hline (Guo et al., 2018) & $\begin{array}{l}\text { Early reading / emerging reading, grammar and spelling, early writing / emerging writing, combination of } \\
\text { reading and writing, individualized instruction }\end{array}$ & Not yet \\
\hline (Berninger et al., 2017) & Disability, dyslexia, dysgraphia & 7.53 \\
\hline (Jiménez, 2017) & $\begin{array}{l}\text { Skill / ability, disability, early writing / emergent writing, transcription, text generation and composition, } \\
\text { spelling }\end{array}$ & 3.76 \\
\hline (Bingham et al., 2017) & Early writing / emergent writing, text generation and composition & 6.52 \\
\hline (Camacho \& Alves, 2017) & Skill lists, parents teaching writing, early writing / emerging writing, text generation and composition & 1.24 \\
\hline (Justice et al., 2017) & Early reading / emergent reading, emergent literacy & 0.83 \\
\hline (Sinaga \& Feranie, 2017) & Fine motor skills, quality of writing, writing skills with adults & 2.90 \\
\hline (Liao et al., 2015) & Satisfaction, skill / ability, Skill lists & 5.99 \\
\hline (Zhang et al., 2017) & $\begin{array}{l}\text { Skill / ability, Skill lists, grammar or spelling, Early writing / emergent writing, text generation and compo- } \\
\text { sition, phonological awareness and phonology, emergent literacy }\end{array}$ & 1.24 \\
\hline (Pavelko et al., 2017) & $\begin{array}{l}\text { Satisfaction, skill / ability, Skill lists, disability, Early writing / emergent writing, text generation and compo- } \\
\text { sition, authentic material, oral language and oral narrative }\end{array}$ & 0.54 \\
\hline (Daffern et al., 2017) & $\begin{array}{l}\text { Skill lists, ICT mediation, grammar and spelling, punctuation management, text generation and composi- } \\
\text { tion }\end{array}$ & 0.41 \\
\hline (Korth et al., 2017) & Skill lists, Early writing / emergent writing, emergent literacy & 0.66 \\
\hline $\begin{array}{l}\text { (Birketveit \& Rimmereide, } \\
\text { 2017) }\end{array}$ & Skill lists, illustrated books & 0.55 \\
\hline $\begin{array}{l}\text { (Rodríguez Fuentes \& Galle- } \\
\text { go Ortega, 2017) }\end{array}$ & ICT mediation & 0.62 \\
\hline $\begin{array}{l}\text { (Jafarigohar \& Mortazavi, } \\
\text { 2017) }\end{array}$ & Skill lists, Cognitive and social skills & Not yet \\
\hline
\end{tabular}

At older ages, fluency was understood as a skill for proper reading through an adequate intonation that obeys punctuation marks. Fluency is also the writing skill meaning proper grammar and composition, along with lexical proficiency as required by the subject and audience.

Adding to the above, coherence in writing (18.9\%) understood as the ability to proficiently convey meaning in written texts was mentioned in studies as a key factor for evidencing the development of writing skills (Bigozzi \& Vettori, 2016; GarcíaSánchez \& de Caso-Fuertes, 2005; Mäki et al., 2001). McMaster, Kunkel, Shin, Jung and Lembke (2018), Gutiérrez-Fresneda (2018) and Puranik, Phillips, Lonigan and Gibson (2018) studied early/emerging writing and reading $(11,1 \%$ and $7,8 \%$ ) and confirmed that there may be considerable individual differences among preschoolers in terms of emerging liter- acy performance. They distinguished two different but interrelated domains: knowledge of the alphabet and phonological awareness.

Early knowledge of the alphabet was found to be a key factor in the development of later reading and writing, but the process draws upon multiple interrelated developmental areas (Dickinson \& McCabe, 2001; Zaretsky et al., 2009). This includes development of gross motor skills, pictography and enjoyable, playful learning; children who receive positive stimuli learn to read and write faster.

In that sense, Troia, Shankland and Wolbers (2012), Mikulski (2006), Mutlu, Cimpolat and Süğümlü (2019) and Christensen (2004) showed that recreational and motivational activities are positively linked to the development of literacy. While the mo- 


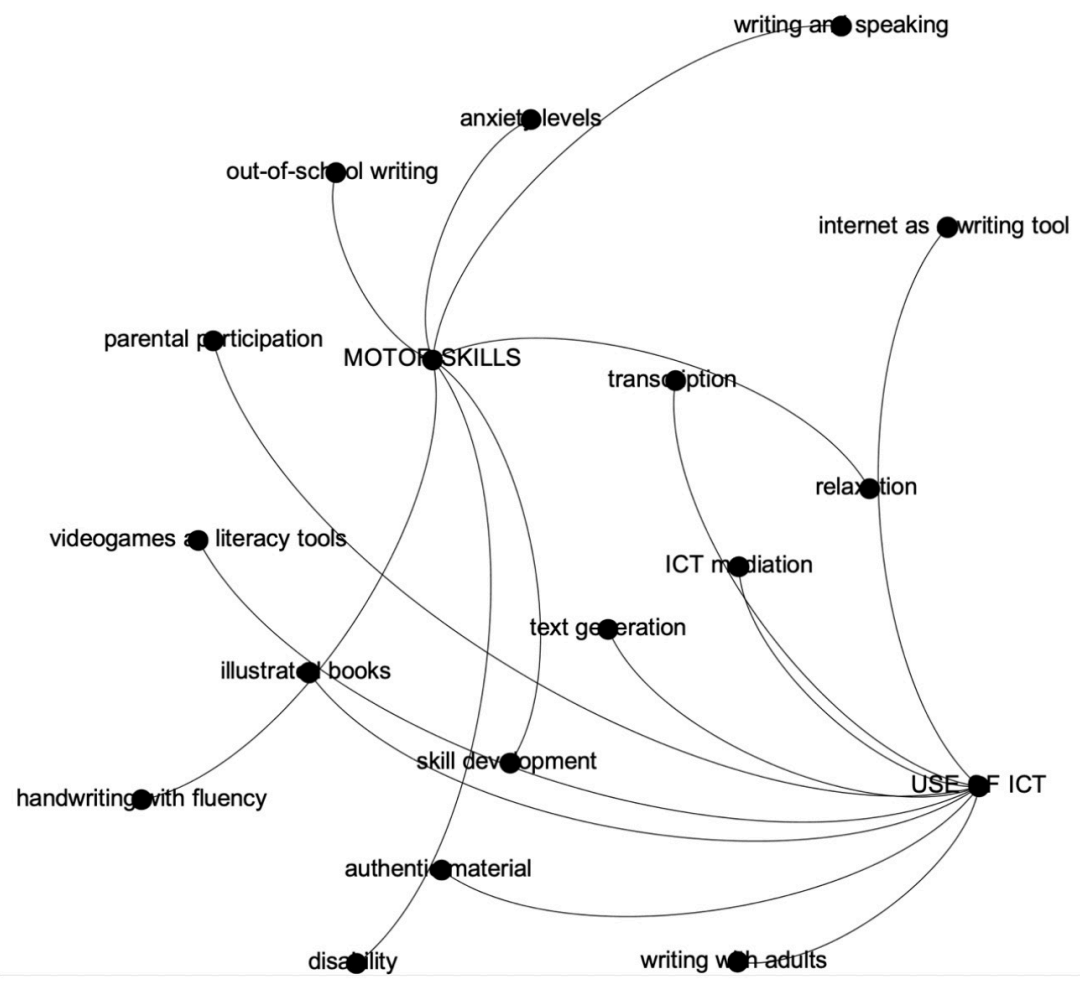

Figure 3. Co-occurrence Mapping and Categorization of Key Ideas Source: Own elaboration

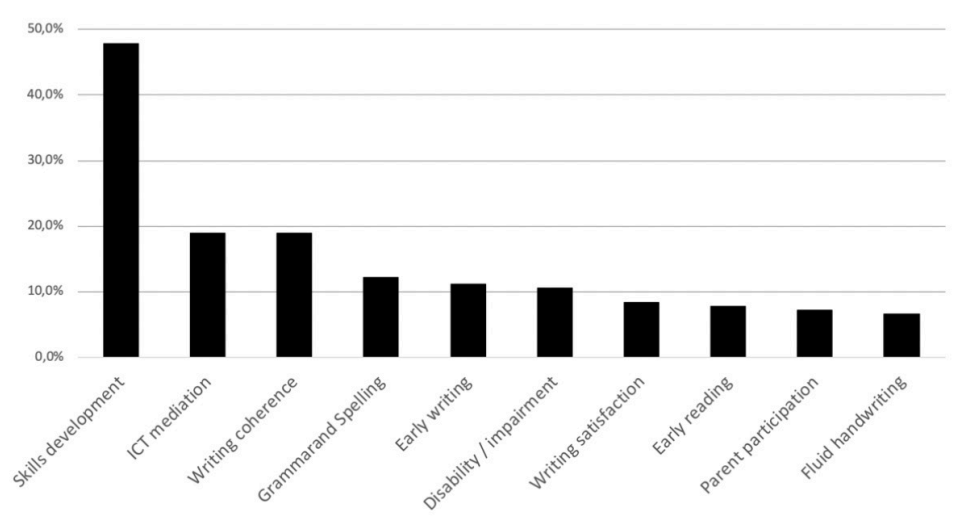

Figure 4. Top 10 Most Frequent Key Ideas Source: Own elaboration

tivation to write can be substantially weaker than the motivation to speak or read, such challenging activities usually have a positive effect on the process.

Finally and expectedly, both disability and impairment in children (10.6\%) held back the development of writing skills (Berninger et al., 2017; Jiménez, 2017; Pennington et al., 2018). Contrariwise, parent participation (7.2\%) had a positive effect on their literacy (Camacho \& Alves, 2017; Hwang et al., 2014; Neumann, 2014). In 2001, the World Health Organization included writing as one of the biggest problems for children with disabilities in school. Indeed, writing is an essential activity allowing students to express their knowledge and ideas and to participate in most of their academic activities. Hence, parental support is crucial for children with disabilities, as they strengthen socialization and literacy development at home to complement what is difficult to implement at school.

The key idea of the development of motor skills showed direct association with seven others, namely: development of skills ( $n=86 ; 47.8 \%)$, disability $(n=19 ; 10.6 \%)$, handwriting with fluency $(n=12 ; 6.7 \%)$, relaxation $(n=2 ; 1.1 \%)$, differences between writing and speaking ( $n=2 ; 1.1 \%)$, anxiety levels ( $n=$ $1 ; 0.6 \%)$ and out-of-school writing $(n=1 ; 0.6 \%)$.

On their part, key ideas related to the use of ICT were: ICT mediation ( $n=34 ; 18.9 \%)$, text generation and composition / writing coherence $(n=34 ; 18.9 \%)$, parental participation ( $n=$ $13 ; 7.2 \%)$, internet as a writing tool $(n=11 ; 7.1 \%)$, transcription $(n=8 ; 4.4 \%)$, writing with adults $(n=6 ; 3.3 \%)$, authentic material $(n=6 ; 3.3 \%)$, videogames as literacy tools $(n=1$; $0.6 \%)$, and, illustrated books ( $n=1 ; 0.6 \%)$.

Drawing on neurodevelopmental theory, Wollscheid, Sjaastad and Tømte (2016) asserted that one of the main factors in the development of basic writing skills is the improvement of other motor developmental skills $(47.8 \%)$ which drive the children's levels of attention. Children begin to create mental structures while exploring the world through body movement during play and locomotion; creating connections by these experiences will soon lead to proper development of 
an enriched lexicon. That is considered a direct and prior step to writing (Aravena \& Quiroga, 2018). Examples of the above process can be found in Kellogg (2008), Kim, Al Otaiba and Wanzek (2015) and Alevriadou and Giaouri (2015).

Writing and ICT skills

A large number of the reviewed studies ( $n=34)$ found that ICT facilitates writing development processes, beyond the operational and process perspective (Hwang et al., 2014; Pennington et al., 2018; Sulak, 2018). Notably positive aspects include the strengthening of writing skills; erasing and correcting without leaving a trace or breaking the paper; and, writing ideas, comments and notes in the same file without messing up what has already been written by the student (Dalton \& Hannafin, 1987; Yamaç \& Ulusoy, 2016).

In addition to the aforementioned, other articles revealed that using word processors as complementary aids improves basic writing skills such as graph recognition, directional left-toright writing, and autonomous visual pursuit of the text line (Chiappe \& González, 2014; Penuel, 2006). Moreover, the use of ICT while learning to write brings in the concept of "collaborative writing", on which many students share documents and contribute to the same texts, either synchronously or asynchronously through the use of ICT tools like wikis or Google Docs. Researchers observed that during the collaborative process the less experienced writers learned from the more advanced or expert ones, and the general quality of the written product increased. This is mainly due to sequential and iterative polishing of the drafts under multilateral supervision and action (Chen \& Yu, 2019; Hadjerrouit, 2011; Karahasanović et al., 2012; Noël \& Robert, 2004; Wang, 2016).

Other research has shown that students significantly improve their writing skills in terms of grammar, mechanics, writing style, and referencing after going through a peer reviewed process (Eaton \& Wade, 2014; Fedewa \& Houghton, 2017).

\section{Discussion}

From the previous section, the researchers found a wide variety of key ideas associated with the development of writing skills. A warning for educational researchers and practitioners, the main idea derived from this review was to acknowledge the relevance of interdisciplinary integration around the development of writing. Literature showed the relevance of motor skills development but also warned that the aforementioned integration currently requires incorporation of ICTs. The emergence of new learning-to-write alternatives beyond motor skills development is related to the evolution of webbased technologies and mobile devices (Lavonen et al., 2008; Serouri, 2017). That should be a structural part of the curricular designs for 21st century schools.

One of the most relevant factors found in writing skills development is the parallel learning of orthographic and grammatical handling associated with phonetic exercises (Guo et al., 2018; Spengler et al., 2018; Zhang et al., 2017). In the early school years, the teacher usually conducts reading exercises to ensure proper pronunciation of the graphs, words, phrases and expressions. A child who acquires phonetic processes wrong tends to write wrong; bad diction is a predictor of later deficiencies in writing, including sentence and paragraph construction (Both-de Vries \& Bus, 2010; Evmenova et al., 2010). For example, the use of subtitled videos where the child can follow the reading creates an association between visual and hearing processing. If this is also associated with a musical component with rhythm tracking and gross movements, the child will improve or acquire proper spelling, along with better grammar.
It was also noticeable that the link between the development of writing and movement is embedded in the term "psychomotor" (Barbot et al., 2012). The development of writing requires maintaining a proper posture and holding the crayon or pencil for long periods of time. Hence, the child must acquire suitable muscular development and gross motor patterns in specific muscle groups. Properly carrying out these processes will eventually enable adequate fine motor development, the final motor scaffolding of writing (Bindman et al., 2014). It was also found that incomplete motor development at home demands corrective physical education processes at school for recovering it and directly addressing the child's writing difficulties.

After analyzing the results of the review, we concurred with the concept that to be able to write is a basic skill for the future learning of more complex knowledge (Flórez Romero et al., 2006). In fact, writing is a foundation to create such a degree of complexity in the child's knowledge.

In addition, we found that writing provides the means for personal reflection, thought, creativity, creation of meaning and exchange of ideas, as well as a complement to other modes of communication in a world of multimodal texts. While writing in the digital age has become increasingly complex and exposed to global scrutiny, being able to write efficiently with correct spelling, grammar and punctuation remains a fundamental part of being a literate writer.

Literature proved that learning to write has a progressive nature, and that it is important to articulate family and school environments in order to achieve such a significant goal. The strengthening of early writing depends to a great extent on a good coordination of the motor, perceptive and cognitive processes. Motivating children for this accomplishment includes the elaboration of creative texts relating to their tastes, interests and game routines (Liao et al., 2015; Sella et al., 2016).

The specialized literature told us that writing can be taught with or without technological mediations. However, much of the reviewed research concluded that the inclusion of Information and Communication Technologies (ICT) was fundamental in the development of basic writing skills (Awada et al., 2019; Mohankumar et al., 2018). Especially in response to the expectations of education in the 21st century, these skills were linked to the further development of informational skills, understood as a set of knowledge, skills and values applied to the "search, recovery, analysis, treatment, communication and application of information" (Monereo \& Badia, 2012, p. 77).

The revision concluded that learning to write in an increasingly technologically mediated, interconnected and global world requires a different perspective of learning to write, perhaps a view where the interdisciplinary exceeds the limits of the compartmentalized and rigid curricula extensively used in elementary and secondary education in developing countries.

We found that such perspective supposes the possibility of curricular articulation of physical education and learning to write in a context where the digital surroundings have a lot to contribute to children and young people's learning experiences. As they are growing in a networked world, playful spaces for learning and motivating are required in the pedagogy for the 21 st century.

\section{References}

Aghajani, M., \& Adloo, M. (2018). The Effect of Online Cooperative Learning on Students' Writing Skills and Attitudes through Telegram Application. International Journal of Instruction, 11(3), 433-448. https://doi.org/10.12973/ iji.2018.11330a 
Ahmed, Y., Wagner, R. K., \& Lopez, D. (2014). Developmental relations between reading and writing at the word, sentence, and text levels: A latent change score analysis. Journal of Educational Psychology, 106(2), 419-434. https://doi.org/10.1037/a0035692

Akkaya, N., \& Kırmızı, F. S. (2010). Relationship between attitudes to reading and time allotted to writing in primary education. Procedia - Social and Behavioral Sciences, 2(2), 4742-4746. https://doi.org/10.1016/j. sbspro.2010.03.761

Alevriadou, A., \& Giaouri, S. (2015). Children with writing disabilities: Revisiting the role of attention and concentration. Horizons in Neuroscience Research, 20, 101-114. Nova Science Publishers, Inc. https://www.scopus.com/inward/record. uri?eid=2-s2.0-84956775708\&partnerID=40\&md5=9f70546231a8e6c52d6911da2f71650f

Aravena, S., \& Quiroga, R. (2018). Desarrollo de la complejidad léxica en dos géneros escritos por estudiantes de distintos grupos socioeconómicos. Onomázein Revista de Lingüística Filología y Traducción, 42, 197-224. https://doi.org/10.7764/onomazein.42.03

Awada, G., Burston, J., \& Ghannage, R. (2019). Effect of student team achievement division through WebQuest on EFL students' argumentative writing skills and their instructors' perceptions. Computer Assisted Language Learning, 1-26. https://doi.org/10.1080/0 9588221.2018 .1558254

Barbot, B., Tan, M., Randi, J., Santa-Donato, G., \& Grigorenko, E. L. (2012). Essential skills for creative writing: Integrating multiple domain-specific perspectives. Thinking Skills and Creativity, 7(3), 209-223. https:// doi.org/10.1016/j.tsc.2012.04.006

Belet Boyacı, Ş. D., \& Güner, M. (2018). The Impact of Authentic Material Use on Development of the Reading Comprehension, Writing Skills and Motivation in Language Course. International Journal of Instruction, 11(2), 351-368. https://doi.org/10.12973/ iji.2018.11224a

Berninger, V., Abbott, R., Cook, C. R., \& Nagy, W. (2017). Relationships of Attention and Executive Functions to Oral Language, Reading, and Writing Skills and Systems in Middle Childhood and Early Adolescence. Journal of Learning Disabilities, 50(4), 434-449. https://doi.org/10.1177/0022219415617167

Bigozzi, L., \& Vettori, G. (2016). To tell a story, to write it: Developmental patterns of narrative skills from preschool to first grade. European Journal of Psychology of Education, 31(4), 461-477. https://doi.org/10.1007/ s10212-015-0273-6

Bindman, S. W., Skibbe, L. E., Hindman, A. H., Aram, D., \& Morrison, F. J. (2014). Parental writing support and preschoolers' early literacy, language, and fine motor skills. Early Childhood Research Quarterly, 29(4), 614624. https://doi.org/10.1016/j.ecresq.2014.07.002

Bingham, G. E., Quinn, M. F., \& Gerde, H. K. (2017). Examining early childhood teachers' writing practices: Associations between pedagogical supports and children's writing skills. Early Childhood Research Quarterly, 39, 35-46. https://doi.org/10.1016/j.ecresq.2017.01.002
Birketveit, A., \& Rimmereide, H. E. (2017). Using authentic picture books and illustrated books to improve L2 writing among 11-year-olds. The Language Learning Journal, 45(1), 100-116. https://doi.org/10.1080/095 71736.2013 .833280

Both-de Vries, A. C., \& Bus, A. G. (2010). The proper name as starting point for basic reading skills. Reading and Writing, 23(2), 173-187. https://doi.org/10.1007/ s11145-008-9158-2

Camacho, A., \& Alves, R. A. (2017). Fostering parental involvement in writing: Development and testing of the program Cultivating Writing. Reading and Writing, 30(2), 253-277. https://doi.org/10.1007/s11145-0169672-6

Chen, W., \& Yu, S. (2019). A longitudinal case study of changes in students' attitudes, participation, and learning in collaborative writing. System, 82, 83-96. https:// doi.org/10.1016/j.system.2019.03.005

Chiappe, A., \& González, A. R. (2014). Los procesadores de texto y los niños escritores: Un estudio de caso. Estudios Pedagógicos, 40(2), 101-115.

Christensen, C. A. (2004). Relationship between orthographic-motor integration and computer use for the production of creative and well-structured written text. British Journal of Educational Psychology, 74(4), 551564. https://doi.org/10.1348/0007099042376373

Daffern, T., Mackenzie, N. M., \& Hemmings, B. (2017). Predictors of writing success: How important are spelling, grammar and punctuation? Australian Journal of Education, 61(1), 75-87. https://doi. org/10.1177/0004944116685319

Dalton, D. W., \& Hannafin, M. J. (1987). The Effects of Word Processing on Written Composition. The Journal of Educational Research, 80(6), 338-342. https://doi.org/ $10.1080 / 00220671.1987 .10885779$

De-Juanas Oliva, Á. (2014). Patrones motores y procesos de adquisición de la lecto-escritura en la etapa de educación primaria. International Journal of Developmental and Educational Psychology, 6(1), 321-326. https:// doi.org/10.17060/ijodaep.2014.n1.v6.750

Dickinson, D. K., \& McCabe, A. (2001). Bringing it all together: The multiple origins, skills, and environmental supports of early literacy. Learning Disabilities Research \& Practice, 16(4), 186-202.

Eaton, C. D., \& Wade, S. (2014). Collaborative Learning Through Formative Peer Review With Technology. PRIMUS, 24(6), 529-543. https://doi.org/10.1080/105 11970.2014 .881442

Erdogan, O. (2011). Relationship between the Phonological Awareness Skills and Writing Skills of the First Year Students at Primary School. Educational Sciences: Theory and Practice, 11(3), 1506-1510.

Evmenova, A. S., Graff, H. J., Jerome, M. K., \& Behrmann, M. M. (2010). Word prediction programs with phonetic spelling support: Performance comparisons and impact on journal writing for students with writing difficulties. Learning Disabilities Research \& Practice, 25(4), 170-182. 
Fedewa, K., \& Houghton, K. (2017). Scaffolding agency and responsibility in cloud-based collaborative writing. In Remote Work and Collaboration: Breakthroughs in Research and Practice (pp. 508-519). IGI Global. https:// doi.org/10.4018/978-1-5225-1918-8

Flórez Romero, R., Arias Velandia, N., \& Guzmán, R. J. (2006). El aprendizaje en la escuela: El lugar de la lectura y la escritura. Educación y Educadores, 9(1), 117-133.

García-Sánchez, J.-N., \& de Caso-Fuertes, A.-M. (2005). Comparison of the effects on writing attitudes and writing self-efficacy of three different training programs in students with learning disabilities. International Journal of Educational Research, 43(4-5), 272-289. https://doi. org/10.1016/j.ijer.2006.06.006

Gaul, D., \& Issartel, J. (2016). Fine motor skill proficiency in typically developing children: On or off the maturation track? Human Movement Science, 46(2), 78-85. https:// doi.org/10.1016/j.humov.2015.12.011

Genlott, A. A., \& Grönlund, Å. (2013). Improving literacy skills through learning reading by writing: The iWTR method presented and tested. Computers \& Education, 67, 98104. https://doi.org/10.1016/j.compedu.2013.03.007

Ghahari, S., \& Farokhnia, F. (2017). Triangulation of language assessment modes: Learning benefits and socio-cognitive prospects. Pedagogies: An International Journal, 12(3), 275-294. https://doi.org/10.1080/155448 0X.2017.1342540

Guo, Y., Sun, S., Puranik, C., \& Breit-Smith, A. (2018). Profiles of Emergent Writing Skills Among Preschool Children. Child \& Youth Care Forum, 47(3), 421-442. https://doi. org/10.1007/s10566-018-9438-1

Gutiérrez-Fresneda, R. (2018). Longitudinal Study on the Development of Literacy Skills During Literacy. Revista de Psicodidáctica (English Ed.), 23(2), 137-143. https://doi. org/10.1016/j.psicoe.2017.09.002

Hadjerrouit, S. (2011). Collaborative writing with wikis: Evaluating students' contributions. IADIS International Conference on Cognition and Exploratory Learning in Digital Age, CELDA 2011, 173-180. https://www.scopus.com/ inward/record.uri?eid=2-s2.0-84883027109\&partnerID=40\&md5=03afef545edbea91423b62b40db0f535

Hier, B. O., \& Eckert, T. L. (2016). Programming generality into a performance feedback writing intervention: $A$ rand omized controlled trial. Journal of School Psychology, 56, 111-131. https://doi.org/10.1016/j.jsp.2016.03.003

Hwang, W.-Y., Chen, H. S. L., Shadiev, R., Huang, R. Y.-M., \& Chen, C.-Y. (2014). Improving English as a foreign language writing in elementary schools using mobile devices in familiar situational contexts. Computer Assisted Language Learning, 27(5), 359-378. https://doi.org/10.1 080/09588221.2012.733711

Jafarigohar, M., \& Mortazavi, M. (2017). The Impact of Scaffolding Mechanisms on EFL Learners' Individual and Socially Shared Metacognition in Writing. Reading \& Writing Quarterly, 33(3), 211-225. https://doi.org/10.10 $80 / 10573569.2016 .1154488$

Jiménez, J. E. (2017). Early Grade Writing Assessment: An Instrument Model. Journal of Learning Disabilities, 50(5), 491-503. https://doi.org/10.1177/0022219416633127
Justice, L. M., Logan, J., \& Kaderavek, J. N. (2017). Longitudinal Impacts of Print-Focused Read-Alouds for Children With Language Impairment. American Journal of Speech-Language Pathology, 26(2), 383-396. https://doi. org/10.1044/2016_AJSLP-15-0200

Karahasanović, A., Brandtzæg, P. B., Lüders, M., Pelt, M., \& Van Den Broeck, M. (2012). Designing collaborative writing applications for children. Proceedings of the IADIS International Conference Web Based Communities and Social Media 2012, IADIS International Conference Collaborative Technologies 2012, 3-12. https://www.scopus.com/ inward/record.uri?eid=2-s2.0-84887479917\&partnerID=40\&md5=f9920105378eee514d046f860b5be62b

Kellogg, R. T. (2008). Training writing skills: A cognitive developmental perspective. Journal of Writing Research, 1(1), 1-26. https://doi.org/10.17239/jowr-2008.01.01.1

Kiiveri, K., \& Määttä, K. (2012). Children's opinions about learning to read. Early Child Development and Care, 182(6), 755-769.

Kim, Y.-S., Al Otaiba, S., \& Wanzek, J. (2015). Kindergarten predictors of third grade writing. Learning and Individual Differences, 37, 27-37. https://doi.org/10.1016/j.lindif.2014.11.009

Korth, B. B., Wimmer, J. J., Wilcox, B., Morrison, T. G., Harward, S., Peterson, N., Simmerman, S., \& Pierce, L. (2017). Practices and Challenges of Writing Instruction in K-2 Classrooms: A Case Study of Five Primary Grade Teachers. Early Childhood Education Journal, 45(2), 237249. https://doi.org/10.1007/s10643-016-0774-1

Koutsoftas, A. D. (2018). Writing-Process Products of Fourthand Sixth-Grade Children: A Descriptive Study. The Elementary School Journal, 118(4), 632-653. https://doi. org/10.1086/697510

Lavallee, M., Robillard, P.-N., \& Mirsalari, R. (2014). Performing Systematic Literature Reviews With Novices: An Iterative Approach. IEEE Transactions on Education, 57(3), 175-181. https://doi.org/10.1109/TE.2013.2292570

Lavonen, J., Juuti, K., \& Meisalo, V. (2008). Reading and writing facilitating ICT use in school science. Proceedings of the 10th IASTED International Conference on Computers and Advanced Technology in Education, 447-452. https://www.scopus.com/inward/ record.uri?eid=2-s2.0-62449317974\&partner$I D=40 \& m d 5=6 c 10 b 5 a e 958 d e b 09 d 8 f 41$ ae766d9e05a

León, A. M., Bravo, C. B., \& Fernández, A. R. (2017). Review of Android and iOS tablet apps in Spanish to improve reading and writing skills of children with dyslexia. Procedia-Social and Behavioral Sciences, 237, 1383-1389.

Liao, C. C. Y., Chang, W.-C., \& Chan, T.-W. (2015). Creation-Island: A game-based writing environment to support students' writing development. Proceedings of the 23rd International Conference on Computers in Education, ICCE 2015, 580-584. https://www.scopus.com/ inward/record.uri?eid=2-s2.0-85030105239\&partnerID =40\&md5=eb5af5d77527fde6c2e7239d3629db81

Mackenzie, N., \& Veresov, N. (2013). How drawing can support writing acquisition: Text construction in early writing from a Vygotskian perspective. Australasian Journal of Early Childhood, 38(4), 22. 
Maftoon, P., \& Seyyedrezaei, S. H. (2012). Good Language Learner: A Case Study of Writing Strategies. Theory and Practice in Language Studies, 2(8), 1597-1602. https://doi.org/10.4304/tpls.2.8.1597-1602

Mäki, H. S., Voeten, M. J. M., Vauras, M. M. S., \& Poskiparta, E. H. (2001). Predicting writing skill development with word recognition and preschool readiness skills. Reading and Writing, 14(7-8), 643-672.

Maldarelli, J. E., Kahrs, B. A., Hunt, S. C., \& Lockman, J. J. (2015). Development of early handwriting: Visual-motor control during letter copying. Developmental Psychology, 51(7), 879-888. https://doi.org/10.1037/ a0039424

Mangen, A., \& Balsvik, L. (2016). Pen or keyboard in beginning writing instruction? Some perspectives from embodied cognition. Trends in Neuroscience and Education, 5(3), 99-106. https://doi.org/10.1016/j. tine.2016.06.003

Martínez Parejo, R. (2016). Desarrollo de la competencia escrita en la enseñanza de lenguas extranjeras a través del uso de dispositivos móviles. Revista Complutense de Educación, 27(2). https://doi.org/10.5209/ rev_RCED.2016.v27.n2.48317

McMaster, K. L., Kunkel, A., Shin, J., Jung, P.-G., \& Lembke, E. (2018). Early Writing Intervention: A Best Evidence Synthesis. Journal of Learning Disabilities, 51(4), 363380. https://doi.org/10.1177/0022219417708169

Mikulski, A. M. (2006). Accent-uating Rules and Relationships: Motivations, Attitudes, and Goals in a Spanish for Native Speakers Class. Foreign Language Annals, 39(4), 660-682. https://doi.org/10.1111/j.1944-9720.2006. tb02282.x

Mohankumar, S., Vijayalakshmi, V., \& Manjusha, C. B. (2018). The effectiveness of Ict in Edifying Language learning: A Quasi -Experimental study. International Journal of Engineering and Technology(UAE), 7(Special Issue 34), 527-529. https://doi.org/10.14419/ijet. v7i2.29.13813

Monereo, C., \& Badia, A. (2012). La competencia informacional desde una perspectiva psicoeducativa: Enseñanza basada en la resolución de problemas prototípicos y emergentes. Revista Española de Documentación Científica, 35(Monográfico), 75-99. https:// doi.org/10.3989/redc.2012.mono.978

Mutlu, H. H., Cinpolat, E., \& Süğümlü, Ü. (2019). Relationship Between Writing Motivation Levels and Writing Skills Among Secondary School Students. International Electronic Journal of Elementary Education, 11(5), 487492. https://doi.org/10.26822/iejee.2019553345

Neumann, M. M. (2014). An examination of touch screen tablets and emergent literacy in Australian pre-school children. Australian Journal of Education, 58(2), 109122. https://doi.org/10.1177/0004944114523368

Noël, S., \& Robert, J.-M. (2004). Empirical Study on Collaborative Writing: What Do Co-authors Do, Use, and Like? Computer Supported Cooperative Work (CSCW), 13(1), 63-89. https://doi.org/10.1023/B:COSU.0000014876.96003.be
Olinghouse, N. G., \& Graham, S. (2009). The relationship between the discourse knowledge and the writing performance of elementary-grade students. Journal of Educational Psychology, 101(1), 37-50. https://doi. org/10.1037/a0013462

Pavelko, S. L., Lieberman, R. J., Schwartz, J., Hahs-Vaughn, D., \& Nye, C. (2017). The development of writing skills in 4-year-old children with and without specific language impairment. Clinical Linguistics \& Phonetics, 31(7-9), 682-696. https://doi.org/10.1080/02699206 .2017 .1310298

Pennington, R. C., Foreman, L. H., \& Gurney, B. N. (2018). An Evaluation of Procedures for Teaching Students With Moderate to Severe Disabilities to Write Sentences. Remedial and Special Education, 39(1), 27-38. https://doi.org/10.1177/0741932517708428

Penuel, W. R. (2006). Implementation and Effects Of Oneto-One Computing Initiatives: A Research Synthesis. Journal of Research on Technology in Education, 38(3), 329-348. https://doi.org/10.1080/15391523.2006.10 782463

Puranik, C. S., Phillips, B. M., Lonigan, C. J., \& Gibson, E. (2018). Home literacy practices and preschool children's emergent writing skills: An initial investigation. Early Childhood Research Quarterly, 42, 228-238. https://doi.org/10.1016/j.ecresq.2017.10.004

Rodríguez Fuentes, A., \& Gallego Ortega, J. L. (2017). Aprendiendo a escribir durante la enseñanza obligatoria ¿deseo o realidad? Calidoscópio, 15(1), 106-125. https://doi.org/10.4013/cld.2017.151.09

Romero, G., Bolli, H., \& Keske-Soares, M. (2005). A terapia em consciência fonológica no processo de alfabetização. Pró-Fono Revista de Atualização Científica, 17(2), 175-184.

Sauvé, L., Fortin, A., Viger, C., \& Landry, F. (2018). Ineffective learning strategies: A significant barrier to post-secondary perseverance. Journal of Further and Higher Education, 42(2), 205-222. https://doi.org/10.1080/0 309877X.2016.1224329

Sella, A. C., Tenório, J. P., Bandini, C. S. M., \& Bandini, H. H. M. (2016). Games as a measure of reading and writing generalization after computerized teaching of reading skills. Psicologia: Reflexão e Crítica, 29(1), 1-12. https://doi.org/10.1186/s41155-016-0039-3

Serouri, H. D. (2017). The impact of ICTs on teaching/learning of writing: Case of explanatory texts in FFL [L'impact des technologies de l'information et de la communication sur l'enseignement/apprentissage de l'écrit: Cas du texte informatif en français langue étrangère]. Synergies Algerie, 25, 91-100.

Sinaga, P., \& Feranie, S. (2017). Enhancing Critical Thinking Skills and Writing Skills through the Variation in Non-Traditional Writing Task. International Journal of Instruction, 10(2), 69-84. https://doi.org/10.12973/ iji.2017.1025a

Sitnikova, M. (2012). Educational Peculiarities and Difficulties of Children with Left Sided Laterality: The Technological Solution of the Problem. Cypriot Journal of Educational Sciences, 7(1), 1-11. 
Smitha, J., \& Renumol, V. G. (2018). Impact of Fine Motor Skil Development App on Handwriting Performance in Children with Dysgraphia: A Pilot Study. Proceedings of the 2nd International Conference on Digital Technology in Education-ICDTE 2018, 11-16. https://doi. org/10.1145/3284497.3284502

Spencer, T. D., \& Petersen, D. B. (2018). Bridging Oral and Written Language: An Oral Narrative Language Intervention Study With Writing Outcomes. Language, Speech, and Hearing Services in Schools, 49(3), 569-581. https:// doi.org/10.1044/2018_LSHSS-17-0030

Spengler, M., Damian, R. I., \& Roberts, B. W. (2018). How you behave in school predicts life success above and beyond family background, broad traits, and cognitive ability. Journal of Personality and Social Psychology, 114(4), 620-636. https://doi.org/10.1037/pspp0000185

Strand, I., \& Nielsen, L. M. (2017). Ict versus craft in design education for the general public. Proceedings of the 19th International Conference on Engineering and Product Design Education: Building Community: Design Education for a Sustainable Future, E and PDE 2017, 360-365. https://www.scopus.com/inward/record. uri?eid $=2$-s2.0-85042118720\&partner $I D=40 \& m$ d5=883d322c0327f75aa5d850cf05f61d6b

Suggate, S., Pufke, E., \& Stoeger, H. (2018). Do fine motor skills contribute to early reading development?: Fine Motor Skills and Early Reading. Journal of Research in Reading, 41(1), 1-19. https://doi.org/10.1111/1467-9817.12081

Sulak, S. E. (2018). Investigation of Writing Habits of Primary School Teachers. International Electronic Journal of Elementary Education, 10(4), 497-504. https://doi. org/10.26822/iejee. 2018438140

Tengku Mahadi, T. S., Md Husain, F., Jaganathan, P., Hassan, A., Syed Fesal, S. N. H., \& Mohamad, A. (2018). Developing Narrative Writing Skills via a Reading Programme for Low English Language Proficiency Undergraduates. GEMA Online ${ }^{\circledR}$ Journal of Language Studies, 18(2), 1-16. https://doi.org/10.17576/gema-2018-1802-01

Troia, G. A., Shankland, R. K., \& Wolbers, K. A. (2012). Motivation Research in Writing: Theoretical and Empirical Considerations. Reading \& Writing Quarterly, 28(1), 5-28. https://doi.org/10.1080/10573569.2012.632729

Vertecchi, B., Poce, A., Agrusti, F., \& Re, M. R. (2016). Pen or keyboard. An empirical study on the effects of technology on writing skills. Cadmo, 24(2), 33-44.

Wang, D. (2016). Exploring and supporting today's collaborative writing. Conference on Human Factors in Computing Systems - Proceedings, 07-12-May-2016, 255-259. https://doi.org/10.1145/2851581.2859013

Warrens, M. J. (2013). Cohen's weighted kappa with additive weights. Advances in Data Analysis and Classification $7(1), 41-55$

Weigel, D. J., Martin, S. S., \& Bennett, K. K. (2010). pathways to literacy: Connections between family assets and preschool children's emergent literacy skills. Journal of Early Childhood Research, 8(1), 5-22. https://doi. org/10.1177/1476718X09345518
Weston-Sementelli, J. L., Allen, L. K., \& McNamara, D. S. (2018). Comprehension and Writing Strategy Training Improves Performance on Content-Specific SourceBased Writing Tasks. International Journal of Artificial Intelligence in Education, 28(1), 106-137. https://doi. org/10.1007/s40593-016-0127-7

Wollscheid, S., Sjaastad, J., \& Tømte, C. (2016). The impact of digital devices vs. Pen(cil) and paper on primary school students' writing skills - A research review. Computers \& Education, 95, 19-35. https://doi.org/10.1016/j. compedu.2015.12.001

Yamaç, A., \& Ulusoy, M. (2016). The effect of digital storytelling in improving the third graders' writing skills. International Electronic Journal of Elementary Education, 9(1), $59-86$.

Zaretsky, E., Kraljevic, J. K., Core, C., \& Lencek, M. (2009). Literacy predictors and early reading and spelling skills as a factor of orthography: Cross-linguistic evidence. Written Language \& Literacy, 12(1), 52-81.

Zhang, C., Bingham, G. E., \& Quinn, M. F. (2017). The associations among preschool children's growth in early reading, executive function, and invented spelling skills. Reading and Writing, 30(8), 1705-1728. https://doi. org/10.1007/s11145-017-9746-0

Zhang, C., \& Quinn, M. F. (2018). Promoting Early Writing Skills through Morning Meeting Routines: Guidelines for Best Practices. Early Childhood Education Journal, 46(5), 547-556. https://doi.org/10.1007/s10643-017-0886-2 